\title{
Haläl Marketing Practices and Performance of Cooperative Societies in Ilorin Metropolis, Kwara State, Nigeria
}

\author{
Mustapha Yusuf Ismaila ${ }^{1 *}$, Abdulazeez Sodiq Olamilekan ${ }^{2}$, Abdul Falilat Ajoke ${ }^{3}$ \\ 1,2,3 Department of Marketing, University of Ilorin, Ilorin, Nigeria
}

\section{Keywords \\ Halāl Marketing \\ Cooperative Societies \\ Product Offering \\ Members' Patronage \\ Dynamic Pricing}

Received: 23 September 2019

Accepted: 17 December 2020

\begin{abstract}
The rise in the number of Muslims who desire to comply with Islamic religion prescriptions had led to the existence of strong demand for haläl products which most business firms now try to supply. This research examined hala $l$ marketing practices and the performance of cooperative societies in Ilorin metropolis. It uses members' patronage of haläl product offering and loyalty to dynamic product pricing as measures of performance. Multi-stage sampling procedure was adopted to determine the suitable sample size from the target population and multiple regression analysis was employed as the analytical technique. Finding revealed that halāl product offering has a significant influence on members' patronage of Islamic cooperative societies.
\end{abstract}

KAUJIE Classification: P1, I45

JEL Classification: I3, M1, M3

(C) 2020 JIBM. All rights reserved.

\section{INTRODUCTION}

Marketing is an aspect of business activities that mainly seek to unravel societal needs and satisfy it in a way that ensures a sustainable marketing environment. This is why Islam and Chandrasekaran (2013) observed that the essence of marketing activity lies in identifying, sensing and probing the needs of customers and meeting those needs profitably. It is an organizational function responsible for identifying the needs of people and putting resources together to satisfy these needs. The success of every firm in any business environment depends on consumers' acceptability of the firm's policies and programs in the marketing decision areas. However, the consumer needs and reactions to these policies and programs are highly vulnerable to changes in the operating environment. Hence, understanding what consumer purchase and why they purchase them became a vital factor in successful marketing operations anywhere in the world.

The aforementioned dynamism results from various factors affecting buyer behavior in the societies where they live. It is then imperative for every marketer to pay apposite attention

\footnotetext{
* Corresponding author: Mustapha Yusuf Ismaila

†Email: ismyoriss@gmail.com
} 
to the trends of things in the market in which they operate. Some scholars such as Kotler and Armstrong (2014) and Pride and Ferrel (2011) unanimously opined that the behaviors of consumers in the market is affected by cultural, social, personal and psychological factors. However, Kotler and Armstrong (2014) pointed out that cultural factors exert the broadest and deepest influence on buyer behavior. Socio-cultural issues consist of a set of morals, insights, likings and beliefs of a particular community or collection of individuals. The culture of a society usually determines the behavior of individuals in that society. According to Khalek (2014), religion is an important sub-culture which exerts the most influence on consumer behavior in every society.

Furthermore, Islam and Chandrasekaran (2013) observed that the tenet of religion centered on the belief and value systems which are expressed in terms of proscriptions, acceptances, sanctions, manners, actions and responses. Every religion has its precepts and tenets and these sometimes revolve around the entire life of her adherents. For instance, Islam prohibits the consumption of certain kinds of foods as specified in the Holy Qur'ān "Forbidden to you (for food) are dead animal, blood, the flesh of swine, and that on which Allah's name has not mentioned while slaughtering.." [Al-Ma'idah 5:3]. The interpretation of this is that Muslims must abide by the restrictions and prohibitions specified in the above surāh and in other different places where it is mentioned in the Holy Book. The surāh goes further to enunciate those prohibitions, which believers are expected to observe. The implication of this is that Muslims (consumers) would tend to boycott all the products which contain ingredients from these food items stated in the verse.

As a result of the above Qur'ānic injunction, practicing Muslims all over the world have become cautious about the halālness of what they consume ranging from foods, financial services, medications, cosmetics, dresses, schooling etc. This is why Famet et al. (2004) observed vehemently that the function of religious beliefs cannot be evaded or unheeded as religious attachment may influence the people's way of live, what they eat, and whom they associate with. This submission accounts for the reason why Delener (1994) advised firms to develop or adopt marketing strategies that consider consumers' religiousness because the tenet of religion focuses on the belief and value systems that are usually expressed in terms of proscriptions, acceptances, sanctions, conducts, actions and responses. Thus, the need for marketers to cater to the wants of practicing Muslims who desire to use or consume products that comply with Islamic teachings gave birth to Islamic marketing or halāl product marketing.

The halāl product industry has high potentials because Islam is the second-largest religion in world with over 1.8 billion followers which represents $24.1 \%$ of the world's population and the majority of its ardent resides in 50 countries of the world (Wikipedia). The potentials of the haläl products market have motivated some firms to consider religion in formulating marketing programme and strategy for their products especially now that a high number of Muslims all over the world are increasingly aware of the need for them to consume products that are Sharía ah compliant (Mustapha et al., 2016). In fact, Berry (2008) asserted that demand for halāl product offerings in some non-Muslim countries for both Muslim and non-Muslim consumers is very strong since the admiration for haläl product offerings are 
increasing owing to consumers' positive perception that halāl product offerings are healthier and harmless. Also, Sandikci (2011) further observed that the connection among Islamic teaching, marketing and consumption is becoming more important every day and any firm which desires to flourish should not toy with because this relationship has resulted in more than 2.3 trillion USD annual halāl marketing value.

Given the aforementioned, many business enterprises now embrace full-fledged halāl marketing operations especially those that operate in financial institutions such as banking, insurance, cooperative societies and other financial services. For instance, some cooperative societies operating in Muslim-dominated areas have discovered that their operational excellence does not only depend on enhancing the socio-economic well-being of their members, but also in embracing halāl marketing practices as a strategy for meeting the needs of their members. Examples of these financial/cooperative societies include Al-Burham, Iman Trust, Al-Mubarak, Al-Hikmah and At-Taqwa. However, the performance of cooperative societies that operate halāl marketing practices has not been adequately researched especially in Nigeria, and by extension in Kwara State. Also, the evaluation of extant works on the subject matter shows that a few empirical studies were carried out on the effect haläl marketing on firm performance, such as Othman et al. (2016), Nordin et al. (2016), Rafiki and Wahab (2013) and Razali et al. (2013). These relate works were carried out in the Asia continent and their findings may not be wholly relevant to our environment. Consequently, the need for this study stems from the rarity of empirical studies on haläl marketing practices and firms' performance in Africa and by extension Nigeria. Hence, the current study explores halāl marketing practices and performance of cooperative societies in Ilorin metropolis of Kwara State, Nigeria.

\section{Objectives of the Study}

The over-all objective of the study is to survey the effect of halāl marketing practices on the performance of Islamic cooperative society, while the specific objectives are to:

i. Determine the extent to which halāl product offering influences members' patronage of Islamic cooperative societies; and

ii. Evaluate the effect of dynamic pricing on the members' loyalty to Islamic cooperative society.

\section{LITERATURE REVIEW}

\section{Overview of Haläl Marketing}

The concept of halāl marketing can be used interchangeably with the concept of Islamic marketing. This is because both terms simply refer to the conception, anticipation and satisfaction of consumers' needs and wants following the Islamic principles that are specified in the Holy Qur'ān and hadith of Holy Prophet Muhammad (SAW). These two sources of Islamic principles are regarded as Sharī'ah or Islamic Jurisprudence and they basically refer to the code that governs the pattern of operations in haläl marketing. Saeed et al. (2001) liken haläl or Islamic marketing to the recognition that value maximization should be built on fair-mindedness and truthfulness for the general well-being of humanity. On his part, Jafari 
(2012) sees Islamic marketing as the understanding of marketing phenomena concerning Islamic values, ethics and practices within the context of Muslims communities. According Alom and Haque (2011) haläl marketing simply denotes the procedure and stratagem (Hikmah) of satisfying needs through haläl (tayyibat) goods and services with the common consent and well-being ( fala $h$ ) of both parties (i.e. consumers and suppliers) to achieve material and divine welfare in this world and afterlife.

\section{Reasons for Haläl Marketing}

Several scholars such as Alserhan and Alserhan (2012) and Islam and Chandrasekaran (2013) have identified some reasons for the growing interest in Shari'ah-compliant marketing activities as well as halāl product consumption. Following are these reasons given by these scholars.

\section{i. Growing Awareness of Islamic Values}

Sandikci (2011) opined that the alertness of Muslims to Islamic values is one major reason for the growing advocacy to sensitize business firms on the need to apply Islamic principles in the process of production, pricing, distribution and communication with the halāl market. He maintained that the middle-class Muslims are becoming more attentive to the provisions in the Qur'ān and Sunnah and this may have resulted from their access to sources of religious knowledge, which are hitherto not easily accessible. A typical Muslim is now aware of almost every single do and don't that his/her religion stipulate so much so that he avoids any misstep in his livelihood (Sandikci, 2011).

\section{ii. The Emergence of Muslim Entrepreneurs}

Many Muslims who understand Islam very well and who are business owners have begun to apply Islamic teachings in their day to day business activities. In the view of Sandikci (2011), the emergence of these Muslim entrepreneurs who are spread across the world had also contributed enormously to the growing rate of hala $\bar{l}$ marketing activities in the global business environment. For instance, Islam and Chandrasekaran (2013) pointed out that Ogilvy and Mather launched 'Ogilvy Noor' which is the world maiden professional Islamic branding consultancy in May 2010. The firm initiated 'Noor Index' that gauges the halālness of goods and services.

\section{iii. Homogeneous Nature of the Muslim Community}

The homogeneity nature of the Muslim communities is an important reason why halāl marketing is getting wide acceptance from marketers and other business owners (Alserhan \& Alserhan, 2012). This simply implies that regardless of where Muslims communities are located, their attitudes and behaviours are similar because they are guided by universal injunctions contained in the Holy Qur'ān and the hadìth. Alserhan and Alserhan (2012) further illustrated that though many factions or sects have erupted in the religion of Islam with diverse ideological backgrounds yet it seems that the groups share the same views concerning matters that do not affect creed and others. Every Muslim in the world is guided by different injunctions in the Holy Qur'ān and the Sunnah of the Prophet (SAW). 


\section{iv. Existence of Strong Demand for Haläl Products}

In the view of Berry (2008) the existence of robust demand for halāl product offerings in some non-Muslim countries, for both Muslim and non-Muslim customers accounted for the development of haläl marketing. He concluded that strong demand exists because of the positive perception people have for halāl goods and services in the market. Affirming this position, Ismoyowati (2015) observed that international consciousness for halāl goods and services is growing and country such as Indonesia is a tremendous market for haläl goods and services. In fact, the Islamic Food and Nutrition Council of America documented in one of her 2009 report that the attention on food being healthful also creates a solid opportunity the for halāl food market as a lifestyle choice.

\section{v. Segmentability of Haläl Market}

The ability of the hala $l$ market to meet up with the criteria for effective market segmentation is another vital reason that facilitated the development of halāl marketing. The haläl market is substantial, accessible, measurable and actionable. The market is substantial because Islam is the second-largest religion in world with over 1.8 billion followers and the hala $l$ product market is projected to raise from 45.3 billion U.S. dollars to over 58.3 billion between year 2016 to year 2022 (Statista, 2018). It is measurable because Adnan (2013) and SandÄśkc Äś (2011) estimated that the haläl market worth more than 2.3 trillion US Dollar in value and the fact that some firms have developed many halāl products to fill the needs of Muslims community confirmed that the haläl market is actionable. In addition, the finding of the study conducted by Ogilvy (2010) also confirmed that the halāl market segment (i.e. Muslim consumers) is accessible, viable and it has tremendous opportunities for marketing and communication programs to which individuals and businesses can give a shot.

\section{Differences between Conventional and Islamic Marketing}

The foremost distinction between conventional and Islamic marketing comes from the sources of regulations guiding their mode of operations. This is the reason why scholars such as Adnan (2013), observed that it is difficult to discover any paradox between the definition of Islamic and conventional marketing and that the only distinction between the two is the assurance of haläl operations which is inherent Islamic marketing. AlSerhan (2011) also opined that whereas satisfying customer needs is the center-point of conventional marketing, it can be contended that in Islamic marketing it is not the customer, but Allah, our Creator whose good pleasure is first and foremost sought by every marketer.

For instance, Kotler and Keller (2009) view conventional marketing as a procedure involving planning and executing the conception, pricing, promotion and distribution of ideas, goods and services to create exchanges that satisfy individual and organizational goals. On the other hand, Hussnain (2011) opined that Islamic marketing is the process of identification and implementation of value maximization strategies for the welfare of the stakeholders in particular, and the society in general, governed by the guidelines given in the Qur'ān and Sunnah.

From these descriptions, one can see that satisfaction of customers' needs and maximization of firms' profit are emphasized by conventional marketers in every transaction; 
while, Islamic marketers embrace Islamic principles in their marketing functions instead of pursuing profit maximization by any means possible. Furthermore, Alom and Haque (2011) asserted that most definitions of conventional marketing did not cover the total welfare of an individual, a community, a society, and a state or the planet as a whole. On his part, Adnan (2013) maintained that a number of the conventional marketing definitions in the literature failed to satisfy the requirements of Islamic marketing. He pointed out that the three things that cannot be found in conventional marketing include the intention which is rooted to Allah, applying Islamic criterion to any concepts throughout the exchange process and making marketing as the most important tool for attaining Allah's blessings.

\section{Characteristics of Islamic Marketing}

The features of Islamic marketing concept are spiritualistic, ethical, realistic, and humanistic (Sula \& Kartajaya, 2006) and a critical look at these four features indicate that a virtuous relationship between the five pillars of Islam and its implementation (Hejase et al., 2012). The concepts are briefly discussed below:

i. Spiritualistic: This feature incorporates all aspects of halāl marketing teachings. It suggests that every marketing operation and activities should follow the traditions and rulings of the Qur'ān and hadīth of Prophet Muhammed (SAW). In addition, halāl marketers should wholly trust that Islamic law and Jurisprudence are the decisive rules that should be used as a guide in all marketing transactions (Arham, 2010).

ii. Ethical: Ethics simply refers to the moral values that govern every individual's actions or conduct of activities. The spiritual enrichment contained in haläl marketing forms the Islamic morals within which business transactions are to be executed. Sula and Kartajaya (2006) observed that one of the features every Islamic marketer should uphold in the conduct of their activities is ethical consideration which is based on Islamic teachings. Consequently, haläl marketers should conduct their activities and themselves in line with the teachings of Islamic rules and regulations.

iii. Realistic: According to Hejase et al. (2012) halāl marketers ought not be too "inflexible" in practicing hala $l$ marketing, so long the actions they are to perform do not infringe Islamic laws. However, it should be noted that being pragmatic does not mean that in the case of "emergency", halāl marketers can compromise and overstep the ethics of Islamic laws. Sula and Kartajaya (2006) further cautioned that halāl marketers should be courageous enough to distinguish themselves from other marketers who slightly use or do not use Islamic philosophies in carrying out their marketing activities.

iv. Humanistic: Sula and Kartajaya (2006) asserted that humanistic as a feature of Islamic marketing teaches individuals the morals that differentiate them from any other beings inhabiting this planet. Hence, Islamic marketers ought to be able to distance themselves from inhumane desires such as greed, cheating, false information, deception etc.

\section{The Haläl Marketing Mix}

According to Mustapha et al. (2016), the review of the extant literature on Islamic /halāl marketing shows that there is no consensus on the number of hala $l$ marketing mix elements 
(number of Ps) among the scholars in this area. Some scholars such as Hassan et al. (2008) discussed five halāl marketing elements within the context of Islamic ethics, while Abuznaid (2012) on his part, discussed nine Ps of marketing from the perspective of Islamic/halāl marketing. However, this study concisely discusses the first two marketing mix elements, which are product and price.

\section{Halāl Product and Members' Patronage of Islamic Cooperative Society}

The term haläl means allowable or legal. It is generally used to refer to anything that the religion of Islam approves of. According to Wahab (2004), when the word halāl is used concerning food in the course of business, it connotes lawful products. Similarly, halāl is a expression signifying or possible to be understood as permission by the religion of Islam to devour specific items or use the items. By implication, it indicates that such items should not contain any part of substance which is prohibited by the Sharī'ah.

This study defines a halāl product as anything considered permissible in Islam which an individual or company offers to customers for consumption and satisfaction of their wants. "The haläl is that which Allah has made lawful in His book and the harām is that which He has forbidden, and that concerning which He is silent, He has allowed as a favour to you", (see: Ibn Majah, No 3367). But, it is not possible to be aware of halāl product by relying on the Holy Qur'ān alone; there is need to also refer to the hadith going by the verse of the Qur'ān (4:65) which states: 'But no, by your Lord, they can have no faith, until they make you (O Muhammad SAW) judge in all disputes between them, and find in themselves no resistance against your decisions, and accept (them) with full submission'. The relevance of this injunction to the Muslim Ummah as embodied in this verse is not limited to the people who were around during the lifetime of the Prophet (SAW). The application of the verse remains in existence till the last day (i.e. Day of Judgment). The guidance the Prophet (SAW) proclaimed on behalf of Allah (SAW), and the way in which he followed Allah's (SAW) directions and inspirations will eternally remain a general criterion for the Muslim Ummah. Indeed, acknowledgement of that direction as the ultimate authority is a prerequisite of true belief. This doctrine was enunciated by our Holy Prophet (SAW) in the following hadìth transmitted by Abu al-Qasim Isma'il b. Muhammad al-Isfahani: 'None of you can become a believer until his desires become submissive to what I have brought (i.e. my teachings).' (Cited by al-Nawawi in al-Arba'in, see the tradition no. 41).

Thus, a Muslim is obliged to accept what has been declared as either halāl or harām in the Qur'ān and hadīth because the two are the foremost sources of Islamic laws and they both give clear direction on what Muslims are expected to consume. Qur'ān 16:44 (surāh Al-Nahl) states "with Clear Signs and Books (We sent the Messengers). And We have also sent down unto you (O Muhammad (SAW) the dhikr [reminder and the advice (i.e. the Qur'ān)], that you may explain clearly to men what is sent down to them, and that they may give thought". Concerning this Qur'annic verse, it is worthy to remind here that the responsibility of rationalizing the teachings of the Holy Qur'ān was designed by Almighty Allah (SWA) to be done by the Holy Prophet Mohammed (SAW) not only through sermon but also by demonstrating practically to the Muslim Ummah (Community). It was required 
that he should organize, under his leadership, an Ummah and set up under the principles of the Holy Qur'ān. This responsibility of the Prophet (S.A.W.) has been stated here principally to show the wisdom of sending a man as a Messenger, for, if not the Holy Qur'ān could have been sent through the angels or could have been printed and sent directly to each man. But in this way; that purpose for which Allah (SWA) in His wisdom, Bounty and Providence designed to send the Book could not have been served. That purpose required that the Holy Qur'ān should be brought by a perfect person, who should present it in piecemeal, explain its meaning, eliminate the difficulties and doubts, answer objections etc. and above all, he should also show towards those who rejected and opposed it that kind of behavior and attitude which are worthy of the bearer of the Holy Qur'ān. On the other hand, he should also guide those who believed in it in every aspect of life and set before them his excellent pattern of life. Then he should train them individually and collectively on the principles of the Holy Qur'ān; so as to make them a model society for the rest of mankind.

The Islamic cooperative society offers a number of goods and services to their current and potential members. These products include food and beverages, personal home care, financial services, travel and tours (haji pilgrimage), hospitality, automobile hire purchase, mortgage etc. Experience has, however, shown that financial services form the basis of most Islamic cooperative society operations in Kwara State. At the mention of financial product in the Islamic sphere, it is assumed that it will be devoid of rib $\bar{a}$; Riba is an Arabic word which means usury or interest in English. It is the main factor that sets Islamic financial institutions apart from conventional financial institutions. This is because the Qur'ān issues a stern warning against the consumption of $r i b \bar{a}$ and the sin attached to its consumption is so great that Allah (SWA) announces a war with any anyone who persists in its consumption having known the truth. Perhaps, the increasing awareness of Muslims about this strict prohibition makes them flee away from rib $\bar{a}$ (interest) based financial outlets for Islamic cooperative societies, which offer financial products such as mudārabah, murābahah, ijārah etc. from which they can benefit from as members. Besides rendering financial services to their members, Islamic cooperative societies run commercial operations which take the form of buying goods in bulk and selling them to members mostly at competitive prices.

In determining haläl compliance of a product, we might need to look at some other aspects of product decisions such as haläl packaging, ingredients and branding. From the Islamic context, the packaging material must be free from any substances that are classified as unclean. It is also important that each package is marked in a way that is easy to read, durable and labeled with true information so as not to deceive the buyers (Othman et al., 2016). Furthermore, Hazair (2007) pointed out that halāl products must be packaged in line with Shari'ah injunctions such that the images printed on the product package should not overstep halāl concepts, pictures should not stimulate any unkind feelings and appropriate information such as known haläl logo, and brand name should be made available.

However, that a product carries haläl logo doesn't guarantee complete confidence in consumers as it has been found that some products that are non-Shari'‘ ah like pork are now packaged and labeled as haläl in some situations. This means that the haläl logo may even be doubted in some situations (Hong, 2007). Similarly, the type of ingredients used in 
manufacturing a product would also affect consumer patronage. Kolovoes (2006) opined that ingredients refer to a base material (modified natural state or semi-processed) which has been used by producers as an input in the manufacturing process. Therefore, the determination of a lawful ingredient is guaranteed through the usage of material that is not prohibited by Islamic laws. For instance, consumers consider the nature of ingredients used in making the products to ascertain whether or not the products contain haläl ingredients. This proposition was given by Golnaz et al. (2012) when they opined that consumers' behavior towards food is extremely related to variables like marketing information, situation and food-specific properties which include product ingredients. Thus, Muslim's familiarity with product ingredients will guide their choice of affiliation as they would merely tend towards cooperative societies which offer products that are made from haläl ingredients.

Branding is another aspect of product offering that members can be watchful of. To Kotler and Amstrong (2014), a brand represents the purchasers' perception and feelings towards products and everything about the good or service that has meaning to consumers. There is hardly a single product today that can survive without branding. Aside from its use for preventing adulteration, branding now plays a vital role in instilling a high level of confidence in target customers and it must be noted that a brand is not just merely a name or symbol, it is more than that. Every brand name signals numerous meanings, which are physically and passionately linked to the goods or services that consumers purchased. According to Alhersan (2010), Islamic brands can be categorized into four viz;

i. True Islamic Brands: These are brands which are manufactured in Islamic countries for Muslim consumers;

ii. Traditional Islamic Brands: These are brands that are presumed to be halāl because they are made in Islamic countries for Muslim consumers;

iii. Inbound Islamic Brands: These types of brands come from Islamic countries even though they are not essentially meant for Muslim consumers; and

iv. Outbound Islamic Brands: This category of brands originates from non-Islamic countries although they are not necessarily intended for Muslim customers.

More than ever, Muslims nowadays have become vigilant of what, when, where, how, from whom and how much to consume. They often focus on branding to be safe from consuming forbidden goods. This suggests that a typical Muslim would not buy a product if he is not familiar with the brand even though such a product bears haläl certification. Consequently, the awareness of the brand existence determines the product saleability in any Islamic cooperative society (Wilson \& Liu, 2011). The study conducted by Golnaz et al. (2012) also agreed to this assertion as it showed that product brand had tremendously shaped consumers' self-confidence in purchasing and consuming haläl labeled food for it shows the "haläl" of the goods and services.

\section{Haläl Documentation}

The haläl certificate is a paper which ensures that goods and services intended for the consumption of Muslim Ummah meet with the prerequisite of Shari' 'ah, hence, fit for consumption in Muslim dominated nations and Western world where we have considerable 
cluster of people who are Muslims (e.g. France, Germany, United Kingdom, Spain etc.). Halal certification is the procedure that ensures that the characteristics and value of the goods and services are grounded on the guidelines established by the Islamic Council which permit the use of the halāl mark. It's mostly applied to meat products and other food items such as milk, canned food and additives. For instance, for meat products, haläl certificate endorses that the animals were slaughtered in a single cut, thoroughly bled, and their meat has not been in contact with animals slaughtered otherwise. According to Global Negotiator, 2020 goods and services that are haläl certified are usually marked with a halāl symbol, or simply with letter M. Countries across the globe have different haläl certification bodies that regulate the halāl certification process, which ensures that the quality of the goods and services produced are based on the rules established by the appointed Islamic Council. For instance, we have halāl Montreal Certification Authority in Canada, Shandong halāl certification Service (SHC), China, Egyptian Organisation for Standardisation and Quality (EOS), Egypt, Halāl Control GmbH Inspection and Certification, Germany and World Haläl Authority, Italy. In Japan, Japan Halāl Association, the Haläl Institute of Spain in Spain, Haläl Certification Europe (HCE) in the United Kingdom and Islamic Food and Nutrition Council of American in America. In Nigeria, the TMC Haläl Authority is one of the approved certification and quality assurance bodies of The Muslim Congress. The aim of the body is to evolve halāl products standards and conduct inspection of goods and services in line with Islamic Laws (Shari' ${ }^{-}$ah) and in accord with globally recognized and dependable standards for both national and international consumers. It aims to achieve this by developing halāl product standards and accreditation processes and procedures for halāl products certification purposes.

\section{Halāl Certification Process}

Halal product refers to good or service which meets all the prerequisites for food safety and hygiene, whose composition does not contain a single ingredient that is forbidden for Muslims to use, which applies the requirements of haläl production standards, and which does not use forbidden raw materials and other resources(halalcert.com.ng). The halāl standard is an article that clearly defines process of halal accreditation. The five steps process for granting Haläl Certificate at TMC Halal authority (halalcert.com.ng) includes:

1. Halāl certification application

2. Application evaluation

3. Haläl certification agreement and price quote

4. On-site audit

5. Certification decision

\section{Dynamic Pricing and Members Loyalty to Islamic Cooperative Society}

Price is one of the variables which influence consumer's purchasing decision in the most market and this is because price sometime signifies the quality and benefits of purchasing a product. Price is the second component of the marketing mix elements and it is an important marketing decision area because it is the only clear factor that create revenue and provides an obvious indication of accomplishment or failure of goods and services (Al-Salamin \& 
Al-Hassan, 2016). Therefore, adequate attention must be paid to it to achieve the company objectives in both short and long runs. Islam as a religion allows profit-making in any dealing which a Muslim is engaged in and the basis for this is laid down clearly in surāh Al-Baqarah (2:275), wherein Allah (SWA) says: "...whereas Allah has permitted trading and forbidden riba (usury)." This verse signals that a Muslim is permitted to exchange his wares for something in return, which may be in cash and kind.

The word riba in Arabic grammatically implies 'to nurture, to surpass, to rise'; but theoretically, rib $\bar{a}$ suggests the sum of money which a creditor receives from a debtor at a fixed or predetermined amount of interest. Different types of interest transactions were in vogue during the period of the revelation of the Holy Qur'ān and these dealings were designated as riba $\bar{a}$ by the Arabs. Amongst these types of riba were:

i. In which the seller sold an object and specified a limit of time for the payment of the price, specifying that if the buyer failed to pay within the stated time, he would extend the time limit but rise the price of the object;

ii. In which a gentleman lent a sum of money to other gentleman and specified that the debtor should return a predetermined sum in excess of the amount lent within a specified period of time; and

iii. In which the debtor and seller arranged that the former would pay back the loan within a specific time limit at a fixed rate of interest, and that if he failed to do so within the limit, the lender would extend the period of the time limit, but at the same time would increase the rate of interest. It was as a result of interest transactions ( $r i b \bar{a})$ such as these that the above Qur'ānic verse was revealed by Almighty Allah (SWA) to prevent injustice associated with these types of interest transactions.

There are a number of methods of setting prices in literature such as cost-plus, target return on investment, going rate, competitive bidding etc. Conversely, a common way of pricing products by firms is through setting a reasonable price above the cost of the product and this simple method of fixing price is known as cost-plus. However, these days dynamic pricing seems to be favored by both, companies and customers. Dynamic pricing encompasses altering prices recurrently to meet the physiognomies and needs of individual consumers and circumstances (Kotler \& Armstrong, 2014). Sahay (2007) opined that firms can attain rise in profit substantially if they appropriately applied dynamic pricing strategy. Customers mostly select to suspend buying in the anticipation of upcoming discounts (Chaitanya et al., 2018). This means that the dynamic pricing method is favored by them as they vary in their abilities to pay as well as in their socio-economic situations.

Aside from that, Islam acknowledges that human beings are not created equally and Allah has made us superior over one another even in terms of finance. "And Allah has preferred some of you above others in wealth and properties.." (Qur'ān 16:71). The simple interpretation of this verse is that Allah had not equally blessed His creators and those whom Allah has given more supplies than other people ought to Shari' 'ah it with the less privileges in the society. If not, they shall be guilty of ungratefulness to Allah with respect to the affluence with which Allah (SWA) has provided them with. Our condition can, therefore, differ in some circumstances, thereby affecting how we react to price. Thus, it behoves every company to 
factor in these variations in her pricing activity. Meanwhile, dynamic pricing should not only be concerned with buyer characteristics but it also must consider changes in the environment, all in the interest of the target customers without hindering the actualization of organizational goals and objectives. Therefore, Islamic cooperative societies need to adopt price adjustment strategies such as discounts and allowances during certain occasions like Eid festive periods, ceremonies (child naming, wedding etc), Ramadan, Hajj etc. Gedenk (2002) identified the short term and longterm effects of this form of dynamic pricing on firms/cooperative societies' activities. According to him, in the short run, members would tend to switch/patronize the particular cooperative society that offers dynamic prices in form of price discounts and new customers may also be attracted through the same dynamic pricing strategy. Meanwhile, customers' loyalty is created via price promotions in the long run and this eventually makes them committed to the firm.

Islamic cooperative society is expected to be a haven of convenience for all her members. However, this may not be realized if the society fixes price indiscreetly without taking cognizance of the variations in the financial capacity and socio-economic situations of the members. The realization of dynamic pricing in organizations, therefore, depends on the ability to divide buyers into diverse groups with dissimilar levels of preparedness to pay (Dimicco et al., 2003). The crux of the matter is that the price of goods stocked by Islamic cooperative societies can be relaxed for poor members, either by the sacrifice made by a seemingly opulent faction of the society or better yet, through the significant reduction on the price that has been received from the market due to bulk purchase. There is no gainsaying that if this occurs, some level of confidence would be instilled in the members so much so that they become loyal to the society. Their loyalty can be shown by spreading good word of mouth to families, friends, neighbors, colleagues etc. and all these would earn the organization/cooperative society a positive image in its area of operations. Although one may raise the concern that this practice is unfair, it should be noted that purchasers' perspectives of the fair-mindedness of dynamic pricing depends on the extent of information released to them. So, the rich members can be exposed to the huge benefits derivable from generosity and kindness to the poor as contained in the divine scripture.

\section{Empirical Framework}

Haläl marketing can no longer be said to be in its embryonic phase given the quantum of studies that were carried out in this field. Some of the studies have examined the impact of haläl marketing on consumer behavior, while others examined the effect of haläl marketing on organizational performance. Some of these studies are reviewed here to bring out the state of knowledge in this area.

The work of Golnaz et al. (2012) assessed consumers' confidence in halāl labeled manufactured food in Malaysia. The study surveyed the opinions of 1560 Muslim respondents by means of a structured questionnaire which assessed purchasers' extent of confidence in factory-made halāl logo and labeled food items. The study used the logit model to discover that many socio-economic/demographic and attitudinal features of respondents considerably influence their extent of confidence in the halalness of factory-made food items with the 
haläl logo. It was also revealed that the respondents were reasonably concerned about food labeling or the information regarding the components used in producing the goods. It was concluded that Muslim customers do not have other means to determine whether or not factory-made food items are haläl or not, except by checking on the halāl logo which has been embossed on the packaging of the food items.

The study by Yunus et al. (2014) also examined the perception of Muslims towards the haläl products. The study selected 150 Muslims from diverse places in the Klang Valley area who served as respondents to determine the variables which influence Muslim's buying intention towards Non-Muslim's Haläl packed food manufacturers. Correlational analysis was used as an analytical technique to establish the relationship between three main independent variables of the study (Haläl awareness; Islamic brand, Product ingredients, and Muslim's intention to purchase a Non-Muslim's Halāl packaged +food). The study found that a considerable number of the respondents concurred that Islamic brand influences their self-confidence in the product as they buy hala $l$ packed food item on basis of the brands' information about the product ingredients contained in the label, and that the product ingredients eventually influenced their buying intention.

Furthermore, Othman et al. (2016) studied the effect of halāl dietary practices on organizational performance amongst food producers in Malaysia. In this study, the predictors of firm performance were halāl and thoyyib (internal process) and halāl assurance. Data were obtained from a total of 253 subjects which consist of 184 small and medium organizations and 64 multi-national corporations. Findings of the study exposed that firms' performance is affected more by haläl and thoyyib aspects in the implementation of haläl marketing when likened to the internal process, haläl assurance and staff.

Nordin et al. (2016) surveyed the effect of Haläl certification on firms' financial performance of halāl food industry in Malaysia. The study adopted a cross-sectional sample survey which reached out to a total of seventy-nine thousand three hundred $(79,300)$ food and beverage firms with haläl certifications. The study employed structural equation modelling using a partial least squares (PLS) method to analyze the collected data and the results of the study revealed that haläl certification is extremely related with enhancements in firms' financial performance.

Chaitanya et al. (2018) investigated the way dynamic pricing lead to added product returns using online clothing retail industry in India. The study used all-inclusive sales records of above two million transactions from the Indian online retail market of firms that mostly utilize price promotions. Some econometric models were used to test the hypotheses formulated. The survey responses revealed that over 15 percent of the partakers(respondents) said that they have gained opportunistic returns because of post-purchase price drops. This indicates that consumers can go miles to ensure that they enjoy price discounts.

\section{Theoretical Review}

\section{Theory of Planned Behavior}

The theory is adopted to provide a theoretical base for this study. The theory stresses that intentions to perform certain behaviors by customers (i.e. members of Islamic cooperative 
society) are determined by three independent factors which are attitude, subjective norm and perceived behavioral control (Khalek, 2014). According to Azjen (1991), the theory of planned behavior (TPB) was in many researches relating to buyers' behavior and social psychology. Thus, it is deemed relevant to this research as it seeks to examine the impact of dynamic pricing and halāl product offerings on member's loyalty and patronage respectively.

In this study, attitude, which is the first component of TBP, is portrayed by the member's favorable or unfavorable evaluation to be loyal to or patronize the halāl product offered by Islamic cooperative society. A member would likely be pleased to receive a discount on the prices of products as a result of his indigence during Islamic festivities and this is likely to instill loyalty in him towards the society.

On the other hand, the subjective norm is the perceived social pressure to do or not to do something. The society of Muslims basically includes individuals like family, friends, neighbors, and religious leaders etc. Hence, individual behavior towards the choice products to consume would be guided by the expectation of these people. For instance, religious leaders do a lot to dissuade Muslims from indulging in haräm dealings and the consumption of harām foods and other items. So, the frequency of this warning may constitute a pressure on Muslims to always want to patronize haläl products and it was as a result of this that Borne and Verbeke (2006) describe that Muslims consume haläl goods and services to obey their religious teachings.

Finally, the third component, perceived behavioral control is the trust about control of the opportunities and resources by a person to act in a particular manner (Ajzen, 1991). This study refers to perceived behavioral control as the capacity of a member to be loyal in the form of repeat purchase. Therefore, if a price is fixed dynamically by giving discounts to poor members or offering price-cuts generally on special occasions, it is likely to induce members to commit themselves to society.

\section{Measurement of Performance}

Scholars in the field of management have identified various performance indicators that can be used to measure a firm's performance. For instance, Awang et al. (2008) maintained that a firm's performance measure is usually assessed on sales growth, profit, return on investment, return on assets, customer satisfaction, market share, overall financial performance and product success. Firm's performance could also be measured using different performance indicators such as the measure of profitability, market share and competitiveness, productivity measure, efficiency, and technological advancement. Based on this, the study uses patronage and loyalty which are variables of customer satisfaction as a measure of performance of the selected cooperative societies in the study area.

Halāl Marketing Practices, which is proxy with product offerings and dynamic pricing is the independent variable; and the dependent variable is the Performance of Cooperative Society, which is proxy with customers' patronage and loyalty. The performance of cooperative societies is defined in this study in terms of members' patronage and loyalty to the cooperative operational activities. Specifically, loyalty and patronage as performance indicators are measured in terms of support, physical and emotional commitments given by 
members to the activities of cooperative societies in exchange for the services rendered by the cooperative society which satisfy the needs and desires of the members. The independent variable is defined in terms of product offerings (i.e. Haläl Branding, ingredients and packaging) and dynamic pricing (i.e. price adjustments to individual member's situation/capability and religious season/ festival).

\section{METHODOLOGY}

The study adopted survey research and it was adopted because survey research design is useful in describing the features of a large population and it provides an avenue for more candid and explicit responses than other types of research designs. The population of this study consists of all the thirty-five (35) Islamic cooperative societies (i.e. interest-free) operating within Ilorin Emirate who are on the register of Kwara State Ministry of Commerce, and whose account was audited latest by December 2018. Five Islamic cooperative societies which are Al-Buhan, Iman Trust, Al-Mubarak, Al-Hikmah and At-Taqwa were purposively selected from the study population because their members are well-read and are knowledgeable to provide the required information on the subject matter. Purposive sampling technique which is a non-probability sampling that allows samples to be selected on basis of the population features and the objective of the study. According to Mustapha et al. (2017), there are five Local Government Areas (LGAs) in Ilorin Emirate and LGAs are Asa, Ilorin-south, Ilorin-east, Ilorin-west and Moro. The choice of the study area was informed as a result of her reputation as a cradle of Islamic civilization in the North-central region of Nigeria and the existence of some resourceful Islamic cooperative societies within the emirate. Islamic cooperative societies were selected as a case study because of the apparent opportunity the financial sub-sector has as the only formal institution that operates halāl marketing practices in the study area.

Furthermore, the study adopts Attewell and Rules (1991) guideline to take a hypothetical sample size from the target population that exhibits the desired features which are of interest to the study. Based on this, twenty-five (25) members were taken from each Islamic cooperative society. Hence, a total of one hundred and twenty-five respondents (125) were used as the sample size for the study. A blend of stratified and snowball sampling techniques were employed in the conduct of the study. The stratified sampling technique is a sampling process which allows the total population to be divided into smaller clusters. It is normally utilized when drawing conclusions from diverse sub-segments or strata. On the other hand, snowball sampling which is a non-probability technique allows sample elements possess traits that are rare to locate. This is a sampling method in which existing sample elements provide referrals to recruit the samples required for a study. The stratified sampling technique was used to cluster the cooperative societies into five LGAs of Ilorin Emirate, while snowball sampling technique was utilized to choose 125 respondents out of the total members of the cooperative societies in the study area.

\section{Model Specification}

Model I 


$$
\begin{gathered}
M P(Y)=f(H P O)-------------- \\
M P(Y)=\alpha+\beta 1 H B+\beta 2 H I+\beta 3 H P+\epsilon----------
\end{gathered}
$$

Where:

MP $(\mathrm{Y})=$ Members Patronage (Dependent Variable)

$\mathrm{HPO}=$ Halā $l$ Product Offering (Independent Variable)

$\mathrm{HB}=$ Halā $l$ Branding (as a Proxy of Independent variable)

$\mathrm{HI}=$ Hala $l$ Ingredients (as a Proxy of Independent variable)

$\mathrm{HP}=$ Halāl Packaging (as a Proxy of Independent variable)

$\alpha=$ Regression Constant

$\beta 1-\beta 2=$ Regression Coefficients

$\epsilon=$ Error term

\section{Model II}

$$
M L(Y)=f(D Y N / P R C)-----------------------------
$$

$$
M L(Y)=\alpha+\beta 1 P A I S C+\beta 2 P A R S+\epsilon---------------
$$

Where:

$\operatorname{ML}(\mathrm{Y})=$ Members Loyalty (Dependent Variable)

DP $=$ Dynamic Pricing (Independent Variable)

PAISC $=$ Price Adjustment to Individual situation/capability (as a Proxy of Independent variable)

PARS $=$ Price Adjustment to Religious Season (as a Proxy of Independent variable) $\alpha=$ Regression Constant

$\beta 1-\beta 2=$ Regression Coefficients

$\epsilon=$ Error term

From the above equations, Halāl Marketing Practices which is proxy with haläl product offerings and dynamic pricing is the independent variable, and the dependent variable is the Performance of Islamic Cooperative society which is proxy with customers' patronage and loyalty. These equations suggest that halāl marketing practices such as halāl product offerings (i.e ingredients, branding and packaging), and dynamic pricing (i.e price adjustments to members' situation/capability, religious seasons) affect the performance (i.e. patronage and loyalty). The usage of a model like this is not uncommon as Ali et al. (2016), Chen (2014) and Mustapha et al. (2017) used similar model (i.e. multiple regression analysis) in their studies. The study's data were presented using frequency tables, bar and pie charts. Multiple regression analysis served as an instrument for analyzing the study's data. Statistical Package for Social Sciences (SPSS) version 17.0 was used to run the regression analysis. 


\section{Hypotheses of the Study}

H01: Halāl product offering does not influence members' patronage of Islamic. cooperative societies

H02: Dynamic pricing does not affect members' loyalty to Islamic cooperative societies

\section{Data Presentation and Analysis}

The following section presents the data that were collected from the target population;

TABLE 1

Reliability Statistics

\begin{tabular}{lll}
\hline \hline Construct Name & No. of Items & Cronbach's alpha (a) \\
\hline Halāl ingredients & 3 & 0.906 \\
Halāl branding & 3 & 0.703 \\
Ḧalāl packaging & 3 & 0.712 \\
Individual members' capability & 3 & 0.893 \\
Festive seasons & 3 & 0.827 \\
Patronage & 3 & 0.711 \\
Loyalty & 3 & 0.75 \\
\hline \hline
\end{tabular}

Cronbach's Alpha internal consistency method was used test the reliability of the instrument of the study's research instrument. The index of alpha value ranges between 0 and 1 , with reliability increasing with the increase in value. The coefficient ranges between 0.6-0.7 is a generally accepted rule of thumb that demonstrate acceptable reliability, and 0.7 or higher shows good reliability (Mugenda \& Mugenda, 2003). Thus, since the entire alpha values are greater than 0.7 as shown in Table 1, it implies that the content of the instrument is reliable.

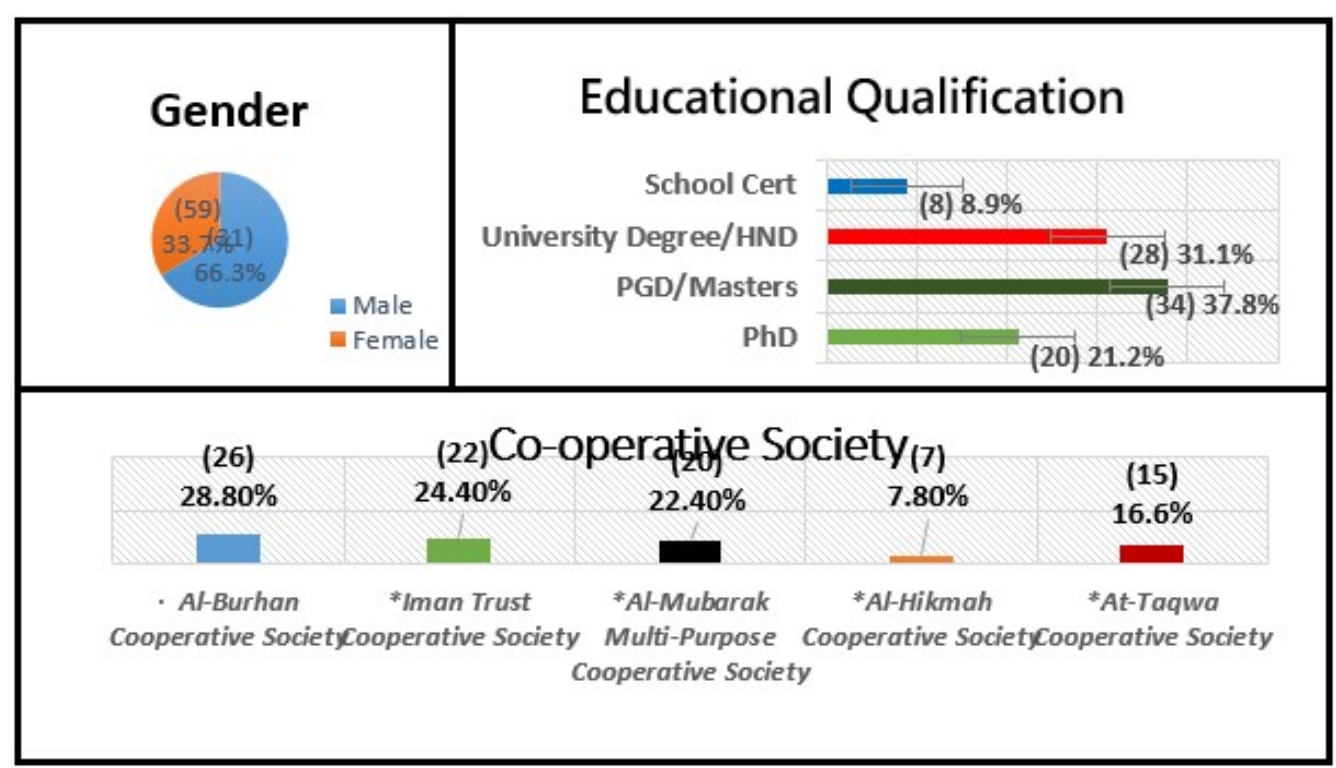

FIGURE 1. Demographic information of the respondents 
Table 2 shows that out of the 90 respondents, male respondents accounted for about $66 \%$ while females accounted for the remaining $34 \%$ of the respondents. This suggests that a considerable number of the respondents were males. This may be due to the religious belief of the study area which encourages males to be more involved in business activities than females. The table also presents the educational qualifications of the respondents. It shows that $31 \%$ of the respondents had University Degrees, $9 \%$ of them had SSCE and 38\% of them had PGD/Masters degrees. The remaining $21 \%$ of the respondents had Ph.D. degrees. Consequently, a substantial number of respondents attended tertiary institutions and had higher educational qualifications. This is an indication that most, if not all the respondents could understand and provide appropriate responses to the questionnaire items. Also, the table shows the cooperative societies that the individual target respondents belong to. It shows that $29 \%$ of the respondents are members of Al-Burhan Cooperative Society, $24 \%$ of them belong to Iman Trust Cooperative Society and $22 \%$ of the respondents operate Al-Mubarak Multi-Purpose Cooperative Society. $8 \%$ of the respondents claimed that they are members of Al-Hikmah Cooperative Society and the remaining 17\% of them are members of At-Taqwa Cooperative Society.

\section{Test of Hypotheses}

This section presents the test of the hypotheses that were earlier stated in the introductory part of this study.

Hypothesis I

Haläl product offering does not influence members' patronage of Islamic cooperative societies;

TABLE 2

Anova (Patronage)

\begin{tabular}{llllll}
\hline \hline Model & Sum of Square & DF & Means Square & F & Sig. \\
\hline Regression & 81.22 & 3 & 27.073 & 7.348 & $.000 \mathrm{~b}$ \\
1 Residual & 250.557 & 68 & 3.685 & & \\
Total & 331.778 & 71 & & & \\
\hline \hline
\end{tabular}

The results in table 3 indicate that the product offerings cause approximately $25 \%$ (i.e $R^{2}=0.245$ ) variations in the members' patronage of Islamic cooperative societies. In other words, $25 \%$ of the changes in members' patronage could be attributed to the halālness of the ingredients, branding and packaging of the product. This implies that the independent variable (halāl product offerings) contributes fairly to members' patronage of Islamic cooperative societies.

Table 2 presents the ANOVA result of the study. The F-statistic as shown in the table above is significant since the probability value of .000 is less than the alpha level of 0.05 , thus the model is fit. Therefore, the null hypothesis, which specifies that halāl product offering does not have a significant influence on members' patronage of Islamic cooperative societies is rejected and the alternative hypothesis, which states that haläl product offering has a significant influence on members' patronage of Islamic cooperative societies is accepted. 
This implies that halāl product offering has a significant influence on the members' patronage of Islamic cooperative societies.

TABLE 3

Results for Main Effects

\begin{tabular}{lllll}
\hline \hline Predictor(s) & \multicolumn{3}{c}{ Patronage } \\
\hline & $\beta$ & $R^{2}$ & $\Delta R^{2}$ & VIF \\
\hline Constant & 5.985 & & & \\
Branding & .046 & & & 1.378 \\
Ingredients & $.891^{* * *}$ & & & 1.493 \\
Packaging & .108 & $.245^{* * *}$ & $.211^{* * *}$ & 1.341 \\
\hline \hline
\end{tabular}

From Table 3, it is shown that for every unit increase in halāl branding activities, there will be 0.046 unit increases in members' patronage, and a unit increase in the use of halāl ingredients will result in 0.891 in sales performance. Also, every unit increase in haläl packaging results in 0.108 members' patronage, if other variables are held constant. In terms of the degree of the coefficient that shows the influence of hala $l$ product offering on members' patronage of Islamic cooperative societies, it is observable that it is only haläl ingredients that has a significant influence on members' patronage of Islamic cooperative societies as shown by coefficient of $(0.891)$ with p-values of 0.000 at $5 \%$ level of significance, while haläl branding and packaging do not have significant influence on members' patronage of Islamic cooperative societies as shown by coefficients of $(0.046 ; .108)$ with $p$-values of 0.804 and .0457 respectively. On the whole, haläl product offering has a significant influence on members' patronage of Islamic cooperative societies. These results show that all the haläl product offering variables (haläl ingredients, ḥaläl branding and haläl packaging) have combined significant influence on members' patronage of Islamic cooperative societies. Based on these results, the study rejects the null hypothesis and upholds that haläl product offering influences members' patronage of Islamic cooperative societies in Ilorin Metropolis of Kwara State.

Therefore, the equation for the dependent variable, that is, patronage $(\mathrm{Y})$ is expressed thus:

$Y=5.985+0.046 H B-0.891 H I-0.108 H P$

The above model showed no problem of multicollinearity among the predictors because the rule of thumb normally used in practice is if a VIF is $>10$, you have high multicollinearity. In this case, with values averagely above 1, the model is in good shape, and the regression is fit.

\section{Test of Hypothesis II}

Dynamic pricing does not have effect on the members' loyalty to Islamic cooperative societies: 
TABLE 4

Anova (Loyalty)

\begin{tabular}{llllll}
\hline \hline Model & Sum of Square & DF & Means Square & F & Sig. \\
\hline Regression & 115.53 & 2 & 57.765 & 14.815 & $.000 \mathrm{~b}$ \\
1 Residual & 292.431 & 75 & 3.899 & & \\
Total & 407.962 & 77 & & & \\
\hline
\end{tabular}

As depicted in table 4, the probability value of 0.000 is less than the alpha value of 0.05 . This indicates that the result obtained is statistically significant at a 0.05 level of significance. For this reason, the null hypothesis, which specifies that Dynamic pricing does not have an effect on the members' loyalty to Islamic cooperative societies is rejected, while alternative hypothesis, which specifies that dynamic pricing has an effect on the members' loyalty to Islamic cooperative societies is accepted. It can, therefore, be said that seasonal and capability-based dynamic pricing jointly have a significant effect on the members' loyalty to Islamic cooperative societies.

TABLE 5

Results for Main Effects

\begin{tabular}{lllll}
\hline \hline Predictor(s) & \multicolumn{3}{c}{ Loyalty } \\
\hline & $\beta$ & $R^{2}$ & $\Delta R^{2}$ & VIF \\
\hline Constant & $6.512^{* * *}$ & & & \\
Capability & $.380^{* *}$ & & & 1.000 \\
Season & $.447^{* *}$ & $.532^{* * *}$ & $.283^{* * *}$ & 1.000 \\
\hline \hline
\end{tabular}

Table 5 further shows the relationship between seasonal and capability-based dynamic pricing and members' loyalty to Islamic cooperative societies. The table shows that the intercept is 6.512 , while the slope for capability and season are 0.380 and 0.447 respectively. Furthermore, the probability values of 0.003 (capability) and 0.001 (season) is indicative of a significant relationship between dynamic pricing and loyalty of members to Islamic cooperative societies since the p-values are both less than the alpha level of 0.05 . Hence, the model can be written as:

$Y=6.512+0.380 P I+0.447 P A R S$

This implies that leaving other factors at 0 , the adoption of capability-based and seasonal dynamic pricing result in $38 \%$ and $45 \%$ increase in the members' propensity to be loyal to cooperative societies respectively. The above model showed no problem of multicollinearity among the predictors because the rule of thumb normally used in practice is if a VIF is $>10$, you have high multicollinearity. In this second case, with all VIFs values at 1 , the model is in good shape, and the regression is fit. 


\section{Discussion of the Findings}

The first goal of this study sought to determine the extent to which haläl product offering influences members' patronage of Islamic cooperative societies. This objective was achieved through the first hypothesis, which postulated that haläl product offering doesn't have a significant influence on members' patronage of Islamic cooperative societies. The halāl product offering was delineated with three proxies; branding, ingredients and packaging. From the result of multiple regression, it was revealed that members' patronage is more influenced by haläl ingredients (0.89) compared to branding (0.046) and packaging (-.108) respectively. This finding is in line with the discoveries of previous empirical works like Golnaz et al. (2012) that found that buyers' behavior towards food item is extremely related to such variables as marketing information, situation and food-specific properties which include product ingredients. Meanwhile, the negative value of the coefficient of packaging somewhat contradicts the same study. This may be because hala $l$ logo, which is a component of packaging, can be doubted in some situations (Hong, 2007). This claim is not however farfetched as it is common to find a non-haläl good and service like flesh of swine being packed and branded as haläl.

Also, the second objective of this study sought to evaluate the effect of dynamic pricing on the members' loyalty to Islamic cooperative society, and the corresponding hypothesis postulated that dynamic pricing does not affect the members' loyalty to Islamic cooperative societies. Dynamic pricing was measured in terms of capability-based and seasonal price adjustment. As shown in table 6, the correlation " $r$ " is 0.532 and this indicates a positive relationship between dynamic pricing and members' loyalty to Islamic cooperative societies. However, it was revealed that $R^{2}$ which is the coefficient of determination is 0.283 and this simply implies that approximately, only $28 \%$ of the change in members' loyalty is explained by the dynamic pricing strategy adopted by Islamic cooperative society.

Additionally, table 5 shows that the intercept and slope for both capability-based and seasonal dynamic pricing strategy are $6.512, .380$ and .447 respectively. Since these values are positive and their corresponding p-values are less than 0.05 , it can be inferred that the adoption of dynamic pricing significantly determines the loyalty of members to Islamic cooperative societies. This finding is to some extent confirmed by the study of Chaitanya et al. (2018) who the way dynamic pricing lead to added product returns using online clothing retail industry in India. Their findings depicted that dynamic pricing can make consumers adjust their purchase patterns all in a bid to benefit from discounts. Gedenk (2002) also acknowledged the effect of dynamic pricing that is deployed in the form of price discounts. According to him, customers would tend to switch/patronize a firm that offers dynamic prices in the form of price discounts and new customers may also be attracted through the same pricing strategy.

\section{Conclusion and Recommendations}

From the analysis of the data collected, this study has established that halāl marketing influences the performance of Islamic cooperative societies; hence, it is concluded that members' patronage of halāl product offerings of Islamic cooperative societies is influenced more by 
halāl product ingredients than halāl product branding and packaging. It is also concluded that dynamic pricing affects the loyalty of members to Islamic cooperative societies.

Based on the above conclusion, the study makes the following recommendations to the management of Islamic cooperative societies and other Islamic oriented business ventures:

i. That the management team of Islamic cooperative societies should deal in product offerings that are primarily made from haläl ingredients. This is can simply be attained by paying attention to the halälness of materials used in making the products they sell to their members and ensure that the operational activities of their cooperative societies comply with Islamic teachings at all times.

ii. The management team of Islamic cooperative societies should intensify the usage of festive seasons and members' capacity to pay dynamic pricing to elicit desired level of loyalty from their members. This can be done by strengthening the established dynamic product pricing strategies that take members' capability /situation or special seasons into consideration in pricing products especially during Ramadan, Eids and other Muslims' festive periods.

\section{REFERENCES}

Abuznaid (2012). Islamic marketing: Addressing the Muslim market. An-Najah University Journal Research (Humanities), 26(6), 1473-1503

Adnan, A. A. (2013). Theoretical framework for Islamic marketing: Do we need a new paradigm. International Journal of Business and Social Science, 4(7), 157-165.

Ajzen, I. (1991). The theory of planned behavior. Organizational Behavior and Human Decision Processes, 50(2), 179-211. doi: https://doi.org/10.1016/0749-5978(91)90020-T

Ali, Z., Shabbir, M. A., Rauf, M., \& Hussain, A. (2016). To assess the impact of social media marketing on consumer perception. International Journal of Academic Research in Accounting, Finance and Management Sciences, 6(3), 69-77.

Alom, M., \& Haque M. (2011). Marketing: An Islamic perspective. World Journal of Social Sciences, 1(3), 71-81.

Alserhan, B. A., \& Alserhan, Z. A. (2012). Researching Muslim consumers: Do they represent the fourth-billion consumer segment? Journal of Islamic Marketing, 3(2), 121-138. doi: https://doi.org/10.1108/17590831211232546

AlSerhan, B. A. (2011). The principles of Islamic marketing (2nd ed.). Gower.

Al-Salamin, H., \& Al-Hassan, E. (2016). The impact of pricing on consumer buying behavior in Saudi Arabia: Al-Hassa case study. European Journal of Business and Management, 8(12), 62-73.

Arham, M. (2010). Islamic perspectives on marketing. Journal of Islamic Marketing, 1(2), 149-164. doi: https://doi.org/10.1108/17590831011055888

Attewell, P., \& Rule, J. B. (1991). Survey and other methodologies applied to IT impact research: Experiences from a comparative study of business computing. Presented at the Information Systems Research Challenges: Survey Research methods.

Awang, K. W., Ishak, N. K., Radzi, S. M., \& Taha, A. Z. (2008). Environmental variables and performance: Evidence from the hotel industry in Malaysia. International Journal of Economics and Management, 2(1), 59-79. 
Berry, B. (2008). Global halāl food market brief. Agriculture and Agri-Food Canada. Retrieved from: http://ats.agr.gc.ca/afr/4491-eng.pdf

Bonne, K., \& Verbeke, W. (2006). Muslim consumer's motivations towards meat consumption in Belgium: qualitative exploratory insights from means-end chain analysis. Anthropology of Food, 5, 2-24. doi: https://doi.org/10.4000/aof.90

Mugenda, O., \& Mugenda, A. (2003). Research methods, quantitative and qualitative approaches. Acts Press.

Chaitanya, B., Antonio, M., Donald, N. \& Zhiji, X. (2018). Opportunistic returns and dynamic pricing: empirical evidence from online retailing in emerging markets (Working Paper No. 19-030). Harvard Business School, Harvard University, Cambridge, MA.

Chen, L. (2014). The influence of social media on consumer behavior: An empirical study on factors influencing consumer purchase intention in China under the social media context (B.Sc. thesis). Aarhus University, Aarhus, Denmark.

Delener, N. (1994). Religious contrasts in consumer decision behaviour patterns: Their dimensions and marketing implications. European Journal of Marketing, 28(5), 36-53. doi: https://doi.org/10.1108/03090569410062023

Dimicco, J., Maes, P., \& Greenwald, A. (2003). Learning curve: A simulation-based approach to dynamic pricing. Electronic Commerce Research, 3(3/4), 245-276. doi: https://doi.org/10.1023/A:1023427023289

Famet, K., Waller, D., \& Erdogan, B. (2004). The influence of religion on attitudes towards the advertising of controversial products. European Journal of Marketing, 38, 537-555. doi: https://doi.org/10.1108/03090560410529204

Gedenk, K. (2002). Sales promotion (1st ed.). Vahlen Publisher.

Golnaz, R., Zainal, A., \& Mad-Nasir, S. (2012). Assessment of consumers' confidence on halāl labelled manufactured food in Malaysia. Social, Science $\mathcal{E}$ Humanities, 20(1), 33-42.

Hassan, A., Chachi, A., \& Abdul-Latiff, S. (2008). Islamic marketing ethics and its impact on customer satisfaction in the Islamic banking industry. Journal of King Abdulaziz University-Islamic Economics, 21(1), 27-46. doi: https://doi.org/10.4197/islec.21-1.2

Hazair, H. P. (2007). Avoid harām names for halāl food. The Brunei Times.

Retrieved from: https://bit.ly/305LnR2

Hejase, H., Hamdar, B., Orfali, M., \& Hejase, A. (2012). Marketing mix: An exploratory research in Syria from an Islamic perspective. American Journal of Scientific Research, 82(82), 33-52.

Hong, L. (2007). NTUC fair price to file police report for tampering of pork packet. Channel News Asia. Retrieved from: https://bit.ly/2ZZCAAp

Hussnain, S. A. (2011). What is Islamic marketing. Global Journal of Management and Business Research, 11(11), 101-103.

Islam, T., \& Chandrasekaran, U. (2013). Halāl marketing: Growing the pie. International Journal of Management Research and Reviews, 3(12), 3938-3948. 
Ismoyowati, D. (2015). Haläl food marketing: A case study on consumer behavior of chicken-based processed food consumption in central part of Java, Indonesia. Agriculture and Agricultural Science Procedia, 3, 169-172. doi: https://doi.org/10.1016/j.aaspro.2015.01.033

Jafari, A. (2012). Islamic marketing: An insight from a critical perspective. Journal of Islamic Marketing, 3(1), 22-34. doi: ttps://doi.org/10.1108/17590831211206563

Khalek, A. A. (2014). Young consumers' attitude towards haläl food outlets and JAKIM's halāl certification in Malaysia. Procedia-Social and Behavioral Sciences, 121, 26-34. doi: https://doi.org/10.1016/j.sbspro.2014.01.1105

Kolovoes, K. G. (2006). Waste ammunition as secondary mineralizing raw material in Portland cement production. Cement Concrete and Residential, 28, 133-143. doi: https://doi.org/10.1016/j.cemconcomp.2005.10.001

Kotler, P. \& Armstrong, G. (2014). Principles of marketing (15th ed.). Pearson Plc.

Mustapha, Y. I., Aremu, M. A., \& Brimah, A. N. (2017). Comparative analysis of service quality and customers' satisfaction of interest and non-interest based cooperative societies in Ilorin Emirate. Jordan Journal of Business Administration, 13(4), 537 -556. doi: https://doi.org/10.35516/0338-013-004-006

Mustapha,Y. I., Aremu, M. A.,Yusuf, A. B., \& Abdul, F. A. ( 2016). The traditional marketing mix elements: A literature review from Islamic perspective. Fountain University Journal of Management and Social Sciences, 5(1),1-8.

Nordin, D., Husain R., Yulia A, Abu Basar S., \& Salleh M. (2016). The effect of halāl certification on financial performance of haläl food companies in Malaysia. In W. Setyawan (Ed.), Proceedings of Unisel Bestari Research Projects, Malaysia.

Ogilvy, M. (2010). A little empathy goes a long way: How brands can engage the American Muslim consumer. Retrieved from: https://cutt.ly/rlClVXY

Othman, B., Shaarani, S. M. D., \& Bahron, A. H. J. (2016). An empirical analysis of haläl practices on organizational performance among food industries. International Journal of Current Research, 8(3), 28909-28919.

Pride, W. M., \& Ferrell, O. C. (2011). Marketing foundations. South Western Cengage Learning.

Rafiki, A., \& Wahab, K. A. (2013). Influences of Islamic practices on small firm performance: a study in North Sumatera, Indonesia. Islamic Management and Business, 5(11), 64-82.

Razalli, M. R., Yusoff, R. Z., \& Mohd Roslan, M. W. (2013). A framework of halāl certification practices for hotel industry. Asian Social Science, 9(11), 316-326. doi: https://doi.org/10.5539/ass.v9n11P316

Saeed, M., Ahmed, Z. U., \& Mukhtar, S. M. (2001). International marketing ethics from an Islamic perspective: A value-maximization approach. Journal of Business Ethics, 32(2), 127-142. doi: https://doi.org/10.1023/A:1010718817155

Sahay, A. (2007). How to reap higher profits with dynamic pricing. MIT Sloan Management Review, 48(4), 53-60. 
Sandikci, O. (2011). Researching Islamic marketing: Past and future perspectives. Journal of Islamic Marketing, 2(3), 246-258.

doi: https://doi.org/10.1108/17590831111164778

Sula, M. S., \& Kartajaya, H. (2006). Sharī'ah marketing. Mizan.

Wahab, A. (2004). Guidelines for the preparation of haläl food and goods for the Muslim consumers. Retrieved from: doi: http://www.sudairy.com.

Wilson, J. \& Liu J, (2010). Shaping the halāl into a brand? Journal of Islamic Marketing, 1(2), 107-123. doi: https://doi.org/10.1108/17590831011055851

Yunus, N. S. N. M., Rashid, W. E. W., Ariffin, N. M., \& Rashid, N. M. (2014). Muslim's purchase intention towards non-Muslim's halāl packaged food manufacturer. ProcediaSocial and Behavioral Sciences, 130, 145-154.

doi: https://doi.org/10.1016/j.sbspro.2014.04.018 